See discussions, stats, and author profiles for this publication at: https://www.researchgate.net/publication/322185346

\title{
The rise of the tent ward: Homeless camps in the era of mass incarceration
}

Article in Political Geography · January 2018

DOI: 10.1016/j.polgeo.2017.11.005

CITATIONS

READS

576

1 author:

Jessie Speer

Syracuse University

10 PUBLICATIONS 60 CITATIONS

SEE PROFILE 


\section{THE RISE OF THE TENT WARD}

\section{ABSTRACT:}

In the era of mass incarceration, services for the homeless often involve mechanisms of confinement and discipline. Over the past decade, homeless communities in cities across the US have developed large-scale homeless encampments in which residents survive outside the purview of official homelessness management systems. Most cities have responded by evicting campers and destroying their tents and shanties. Yet some local governments have instead legalized encampments, while imposing varying degrees of spatial control and surveillance on camp residents. In so doing, they have created unique new spaces for managing homelessness. This article terms these spaces "tent wards" to reflect their dualistic functions of both care and custody. Based on secondary sources and ethnographic research from 2013, I analyze nearly a dozen tent wards in cities across the US, and engage a more in-depth study of the development of such spaces in Fresno, California. I argue that the rise of tent wards calls attention to the need for a renewed focus on the relationship between incarceration and welfare in the US, and the ways in which a diverse range of spaces function together to isolate and discipline entire segments of the

population. 


\section{KEYWORDS:}

homelessness; carceral space; camps; policing; jails; shelters

\section{$\underline{\text { INTRODUCTION }}$}

For over a decade, anti-homeless policing and inadequate shelter in cities across the United States have driven homeless people into encampments located in marginal urban spaces. By 2014, there were an estimated one hundred homeless encampments in the US, ranging in size from a dozen to hundreds of people living collectively (Hunter, et al. 2014). For years, local governments largely responded by evicting campers and destroying their tents and shanties. Yet many cities have also sanctioned homeless encampments and engaged a range of tactics to render them more easily governable. These tactics—most notably the use of rigid discipline and spatial containment—resemble the mode through which carceral institutions govern criminalized populations. I describe these encampments as "tent wards" to reflect how incarceration becomes enmeshed with the provision of care and shelter. These spaces are not simply a cost-effective form of shelter: they are a new node in a wider network of quasi-carceral spaces that govern homeless mobility. This phenomenon sheds light on the ways in which the carceral mode of governance is increasingly fundamental to US homelessness management.

This project emerged out of 24 interviews conducted in 2013 in Fresno, California, at a time when the city was home to some of the largest and most visible tent cities in the nation. Nine of the people interviewed were officials involved in homelessness management, eight were current or former residents of homeless encampments, and seven were activists involved in a local campaign for the right to camp. Participants were identified using snowball sampling, and represented a wide range of backgrounds and experiences. Many participants elected to remain 
anonymous and are identified here using pseudonyms. Research also involved analysis of two local media sources - the Fresno Bee and Community Alliance Newspaper-as well as policy reports, legal documents, and digital sources depicting homeless activism and evictions in Fresno. Finally, this article draws on three months of ethnographic observations in local shelters and encampments in the summer of 2013. Beyond Fresno, I analyze news articles and policy reports on homeless encampments in cities across the nation. After 2013, all tent cities in Fresno were destroyed and the police department set up a taskforce to prevent people from camping again. This article focuses on the period leading up to 2013, as it reflects an era in which cities sought to contain and govern the growing phenomenon of homeless encampments.

\section{MANAGING HOMELESSNESS IN THE ERA OF MASS INCARCERATION}

Mass incarceration in the US today is fundamentally tied to the long history of US poverty management. Piven and Cloward (1971) famously argued that the welfare state functions to regulate the poor by expanding and contracting according to economic shifts. During times of high unemployment, welfare institutions absorb the unemployed to maintain order and pacify civil unrest. In times of low unemployment, degrading welfare conditions ensure that people continue to engage in waged labor. Wacquant (2010) argues that in the contemporary era, welfare has increasingly been replaced by explicitly punitive institutions_-jails and prisonswhich similarly function to regulate labor. The present era of "new punitiveness" has been marked by an explosion in the prison population over the past several decades, coupled with the shrinking of the welfare state. As Gilmore (2007) argues, this carceral boom is grounded in the economic impetus to warehouse poor people of color who have been excluded from labor markets. 
The prison has long been understood as belonging to a broader continuum of institutions that supervise, confine, and normalize residents. Foucault (1995, p. 231) argued that the prison represents the most "complete and austere" institution of control, as techniques of spatial surveillance and punishment are enacted at a range of intensities across a network of different sites. Thus, the prison is a model that influences a variety of "quasicarceral spaces" (Moran, et al., 2017, p. 14). Based on this understanding, geographers have highlighted the diffuse nature of carceral space itself (Gill, 2103; Brown, 2014; Moran, 2015). Indeed, entire neighborhoods can become quasi-carceral when residents are subjected to intense and targeted policing (Davis, 1990; Peck and Theodore, 2008). Simon (2007) argues that across the US, mechanisms of authority that emerged in prison systems are increasingly employed in other venues, including workplaces, families, and schools. Perhaps because of its pervasiveness, the boundaries and characteristics of carceral space remain difficult to pin down. Moran et al. (2017) highlight three “conditions" of carcerality—intent, detriment, and spatiality—which together frame incarceration as the use of space to intentionally impose harm. Drawing on this understanding, I examine "quasi-carceral" sites as employing less severe iterations of the same techniques employed by prisons — surveillance, exclusion, forced mobility, and confinement, for exampleto strategically manage space to the detriment of targeted groups of people.

In the contemporary era, the nexus between homelessness and incarceration has been well documented. Based on extensive survey data, Geller and Curtis (2011) found that recently incarcerated men are at much higher risk of housing insecurity and homelessness. Homeless people, in turn, are jailed anywhere from 8 to 40 times more often than the general population, overwhelmingly on charges of petty public order offenses (Metraux, et al., 2008). Thus, incarceration and homelessness mutually reinforce each other, producing a racialized cycle of 
exclusion and punishment (Gowan, 2002). Metraux, et al. (2008) argue that carceral institutions themselves have come to function as institutions for the management of homelessness. Indeed, in 2008 over 350,000 people lived in shelters (HUD, 2009) and nearly 2.5 million people were incarcerated, nine percent of whom were homeless (Sabol, West, and Cooper, 2009; Greenberg and Rosenheck, 2008). Together, this data suggests that carceral institutions rival homeless shelters as primary sites of homelessness management.

Homeless shelters themselves have a long history of regulating poverty through punitive mechanisms. The contemporary shelter traces its origins to colonial-era poorhouses that historically regulated and confined poor and marginalized populations (Irwin, 1985). Indeed, in their earliest iterations, the poorhouse and the jail were often the same institution. Chapman, Carey and Ben-Moshe (2014) argue that early sites of confinement shared overlapping functions and objectives, such that poorhouses, jails, and even hospitals often served to house as well as punish poor people who were sick, homeless, or disabled. By the 18th century, reform movements spawned the proliferation of institutions differentiated by population. Like their early counterparts, contemporary shelters often involve residents' collective loss of self-determination, tightly scheduled daily routines, and rules against which privileges or punishments are defined (Stark, 1994; Dordick, 1996; DeWard and Moe, 2010). In a 1982 survey, New York City shelter residents rated prisons superior to shelters as a form of housing (Crystal \& Goldstein, 1982). DeWard and Moe (2010) describe a "prisonlike" women's shelter in which purchasing outside food or failing to obtain a job were justifications for being kicked out.

Although shelters are distinct from jails and prisons in the fundamental fact that residents are free to leave, this freedom must be examined in the context of anti-homeless policing. For decades, homeless people have been subject to the perpetual threat of arrest for life-sustaining 
activities like sitting, sleeping, and urinating (Davis, 1990, Mitchell, 1997; Amster, 2008). Beckett and Herbert (2010) argue that in effectively banishing homeless people from public space, anti-homeless policing functions as a carceral mechanism that enforces spatial mobility rather than confinement. Stuart (2013) notes that anti-homeless policing also engages discourses of recovery and treatment, and functions to shepherd people into shelter spaces as well as jails. In recent years, the criminalization of US homelessness has only continued to worsen, with cities across the nation ramping up anti-homeless policing and passing new and more severe restrictions (NLCHP, 2014). Thus, the freedom to leave the shelter is increasingly tenuous, which in turn imbues shelters with a more austere quality.

Yet in the various spaces that house and contain homelessness, punitive logics are never all-encompassing. Indeed, homeless management today is largely turning towards a model of permanent supportive housing that promises to provide housing vouchers without attached disciplinary requirements. Further, a growing body of literature in geography examines how care and compassion are integral to the nature of homelessness management (see generally DeVerteuil, 2006; Deverteuil, et al., 2009). In cities across the US, service workers motivated by deep commitments to compassion and social justice intervene on behalf of people struggling with homelessness. Further, homeless people themselves navigate services according to their own needs, such that they are never fully subject to the disciplinary demands of any single shelter. Such realities make for a complex, nuanced landscape of homelessness that is simultaneously confining and open, punitive and caring. Thus, in the case of homelessness, quasi-carceral spaces are not permanent or fixed, but involve a constant cycling through a diffuse range of both therapeutic and disciplinary institutions. As I show in the following section, the 
space of the tent ward reveals the interplay between these contradictory logics, as welfare and incarceration are deeply enmeshed in sanctioned encampments across the US.

\section{$\underline{\text { THE RISE OF THE TENT WARD }}$}

Prior to the 2008 housing crisis, the contemporary phenomenon of tent cities emerged as a result of anti-homeless policing combined with an inadequate and disciplinary shelter system (Herring and Lutz, 2015). In cities where policing pushed homeless people into marginal urban spaces and shelters became increasingly inhospitable, larger numbers of unsheltered people were left with fewer spaces in the city. Thus, large-scale and enduring homeless encampments developed in cities with under-funded service infrastructures and over-active punitive mechanisms. At the same time, such encampments enabled homeless people to establish a modicum of autonomy from disciplinary homelessness management systems. As Hunter et al. (2014, p. 3) argue, "tent cities can offer individuals and families autonomy, community, security, and privacy in places where shelters have not been able to create such environments."

By and large, cities across the US largely responded to such autonomous spaces through the logic of policing and displacement. Yet over the past decade, many cities began taking a different approach, seeking instead to develop sanctioned encampments, some of which have enabled residents to maintain control over the space of the camp. Such autonomous encampments are governed collectively by residents who develop semi-permanent "tiny house" villages with communal spaces for cooking and relaxing, as well as sharing household chores. Such spaces have been described as representing a new model of urbanism and housing for the homeless (Heben, 2014; Turner, 2017). Portland's Dignity Village is one of the most well-known examples of an autonomous sanctioned encampment. It was formally approved in 2001 after a protracted struggle over the right to camp, and currently houses an intentional community of 
approximately 60 residents. Yet as a precondition to city approval, campers were forced to relocate from a downtown encampment to a fenced-in composting facility seven miles away, squeezed between a state prison and an airport. The remote location makes it difficult for residents to access food, jobs and social services (NCH, 2010). Further, residents are not impervious to the ongoing problem of anti-homeless policing. Thus, even the most radical camp spaces remain subject to carceral management to varying degrees.

Unlike the relative autonomy of Dignity Village, many sanctioned camps are governed according to harsh disciplinary measures (Mitchell, 2012; Herring, 2014). Strategies to control sanctioned encampments include relocating them to more palatable locations, issuing individualized permits to approved residents, and revising local zoning ordinances. Cities that amend local laws to accommodate encampments often disallow any ad hoc or autonomous tent city formation (Loftus-Farren, 2011) and require tent cities to have a supporting host agency and pre-approved city permits. In addition, laws tolerating tent city formation often require encampments to conform to health and safety regulations and mandate "public meetings with adjoining neighborhoods, notification of schools, population limitations, security, screening, and codes of conduct" (Loftus-Farren, 2011, p. 1071).

In many regards, sanctioned encampments of today resemble transient work camps of the Great Depression. As "Hoovervilles" became a staple of the urban landscape, the government responded by instituting an aggressive policy of homeless containment (Mitchell, 2012). In 1933, Congress created the Federal Transient Service (Starr, 1996), and local authorities began to set up federally funded transient camps for homeless migrants. These encampments were designed to "eliminate the tramps" and also to restore homeless "self-respect" through a routine of hard work (Crouse, 1986, p. 153). By 1934, there were 189 federally funded camps across the country 
(Crouse, 1986). Camps were often replete with army-type barracks, running water, and sewage facilities. Authorities guaranteed that residents would be subject to "strict discipline" at all times (Crouse, 1986, p. 154). Thus, the camps were simultaneously highly controlled and spatially isolated, but also designed with the paternalistic aim of restoring the "tramp" to the status of a working person.

Based on policy reports and news coverage of nearly a dozen sanctioned and heavily regulated encampments up until 2013, I argue that such spaces are akin to "tent wards" in that they simultaneously perform custodial and carceral functions. The term "ward" has multiple meanings. It can describe a space within a hospital or prison, as well as a territorial division of a city. In its archaic usage, the "ward" was any place enclosed by the walls of a fortress. Thus, it conveys the geographic quality of spatial separation, as well as the action of watching over and protecting a particular site. When used to describe people, it suggests visual surveillance, care, and paternalism. The "ward of the state," for example, is a person deemed incapable of exercising independent control over her own life, who is thus subject to the authority and safekeeping of the warden. As I show in what follows, these multiple meanings all capture some aspect of tent wards, which sit at the nexus between institutions of care and the punitive state apparatus.

Perhaps the most common feature of tent wards is that they are not managed by homeless communities, but by an outside authority often connected to a law enforcement agency. Private agencies and sheriff's departments have been tasked with operating multiple encampments in California and Florida (NCH, 2010; Hunter, et al., 2014). Another common feature is the use of background checks to control who can and cannot gain residency. At Pinellas Hope in St. Petersberg, Florida, residents are typically referred to the facility by a team of police officers and 
social workers. Before admission, they must undergo a breathalyzer test, background test, and detailed screening (Hunter, et al., 2014). In two Washington cities, municipal code requires an outside manager for all encampments and background checks for residents (Lynnwood, 2014; Spokane, 2014). These practices highlight the implicit goal of funneling homeless people into various spaces - jails, shelters, and tent wards — along a carceral continuum according to their perceived criminality.

As with jails and prisons, tent wards are often fenced in and surveilled. When an encampment developed in Reno in 2008 , the city responded by fencing in and securitizing the property (Loftus-Farren, 2011). In both Lynnwood and Spokane, Washington, municipal code mandates six-foot fencing around the perimeter of all sanctioned encampments, as well as constant surveillance (Lynnwood, 2014; Spokane, 2014). Such requirements suggest a dual function: fencing can be used to conceal homeless encampments from surrounding areas, as well as to afford residents a modicum of privacy. Similarly, surveillance can be a tool to protect residents, as well as police their daily lives. This duality highlights how protective and disciplinary functions become deeply enmeshed in the space of the tent ward.

In addition to fencing, many cities have resorted to isolation as a strategy to conceal tent cities. In St. Petersburg, Pinellas Hope is located ten miles from the downtown area, in an industrial manufacturing zone located on a former swampland (Hunter, et al., 2014). Many residents walk the ten-mile trek each day to get downtown. Safe Harbor is located fifteen miles from downtown and residents "face significant challenges in finding transportation to make appointments and interviews" (Hunter, et al., 2014, p. 54). Similarly, a sanctioned encampment that housed 450 residents in Ontario, California was tucked between abandoned orchards and an airport, on the edges of the city (NCH, 2010). In Washington, municipalities have written spatial 
separation into the local code, with one city mandating "visual separation and buffering" (Lacy, 2014). As with prisons and homeless shelters, this spatial isolation relieves local governments of the problems of NIMBYism by making unpopular communities and spaces largely invisible to the public eye.

Perhaps the most distinctive characteristic of tent wards is the strict enforcement of rules and regulations. A sanctioned encampment in River Haven, California required residents to see a case-manager and attend meetings regularly to demonstrate "an honest plan to end their homelessness" (NCH, 2010, p. 62). In Reno's sanctioned tent city, the government implemented a series of rules and regulations and required that residents "register with the camp, and that they check in with city officials on a weekly basis regarding their progress in finding jobs and other housing options" (Loftus-Farren, 2011, p. 1072). At Pinellas Hope, residents have assigned chores, must post their daily location on a public monitoring board each morning, must wear a wristband at all times, and are searched upon each re-entry (Hunter, et al., 2014). Residents must also meet with a caseworker on a regular basis and are subject to eviction if they create a disturbance. Pinellas Hope has been touted as a success, and nearby communities are considering similar models. Yet a policy report on tent cities describes the facility in less optimistic tones: "The great strength of the organic tent cities was their bottom-up nature. ... City authorities betrayed this vision when they appropriated the tent city model and turned it into a regimented, top-down solution" (Hunter, et al., 2014, pp. 55-56). Ontario's encampment was also notorious for its heavily disciplinary character. Inside, identical army tents were arranged in ordered rows and private security guards monitored residents around the clock. The city established a strict set of rules, including a ban on drugs, alcohol, and pets ( $\mathrm{NCH}, 2010)$. Campers were issued ID cards every 90 days if they complied with these rules and showed "promise and desire to find a job and 
acquire housing" (NCH, 2010, p. 56). They were required to carry their ID cards at all times and were not allowed to bring visitors inside. One camper described the camp as "a prison" (Sanford, 2009). Another woman said of the wristband requirement: "They are tagging us because we are homeless. ... It feels like a concentration camp" (Kelly, 2008). The heavy emphasis on control and rehabilitation suggests that local homelessness management officials viewed the homeless as an unruly population in need of strict discipline and control.

An even starker model explicitly combines sanctioned encampments with carceral institutions. In 2011, the Sheriff's Department in St. Petersberg created a facility called Safe Harbor that was strictly administered by a combination of Sheriff's teams, private security guards, and police officers. Safe Harbor serves as both a shelter and a jail diversion program. Under threat of arrest, homeless residents are given the option to enter Safe Harbor to avoid jail time. However, because homeless people are routinely profiled and targeted for arrest, the diversion program "becomes primarily a means to remove homeless individuals from the streets" (Hunter et al., 2014, p. 53). The facility is located in a former jail, on a concrete block surrounded by high-fences and wiring. It includes an outdoor area with 100 mattresses arranged underneath a roof overhang. The facility has a number of correctional rules, as well as nearconstant surveillance and lack of privacy. Not surprisingly, local homeless people and advocates have criticized Safe Harbor and often refer to it colloquially as a "jail-ter"-a combination jail and shelter (Hunter, et al., 2014). In Key West, officials followed a similar model. They transformed the downtown area into a panhandling-free zone and sent homeless violators to Stock Island's encampment, strategically located next to the county jail. The facility is governed by strict rules that hinder any opportunity for homeless activism (Longley, 2006). It is also miles from downtown, near a landfill dubbed "Mount Trashmore" (Carlson, 2004). Thus, the city 
channels homeless people who would otherwise be destined for jail into a sanctioned encampment that functions simultaneously as a jail and an ad hoc shelter space.

While sanctioned encampments limit homeless autonomy, they often provide amenities that illegal tent cities do not, including sanitation infrastructure, access to regular meals, and security. Sanctioned camps also create opportunities for residents to access much-needed services, such as healthcare or counseling. Yet it is only through government sanction that such encampments are able to access resources, which suggests that people must be disciplined to receive assistance. The concept of the "tent ward" acknowledges this dualistic function of sanctioned encampments as spaces of homeless welfare on the one hand, and surveillance and segregation on the other.

Beyond the tent ward, the contemporary era is notable for the proliferation of detention and refugee camps, which are similarly driven by a combination of care and protection, as well as custody and control (Minca, 2015). Agamben (1998) theorized the camp as the spatial paradigm of modernity and an expression of the crisis of the nation-state's ability to govern its territory. He argued that nation-states transcend this crisis by creating camp spaces-territories outside of the normal juridical order where the protections of national citizenship no longer apply. Minca (2015, p. 79) describes the camp as "a topology of power that, in the name of custody and protection, isolates its inmates from the rest of society, in the attempt to cleanse the body politic from their corrupting or compromising presence." Those who occupy such spaces are banned from the protections of the state while also made vulnerable by that ban. They are thus paradoxically both inside and outside the state, subject to it and excluded from its protections. Through camps, the state contains the mobility of those with "no clear identity and 
fixed location" and interns them in a "spatial limbo, marked by the ambivalence of permanent temporariness" (Minca 2015, p. 80).

Today, refugees represent key figures in theorizations of the camp, as they live permanently between camp spaces, with no clear place of belonging. Scholars have theorized refugee encampments as both quasi-carceral spaces (Felder, Minca and Ong, 2014) and sites of "compassionate repression" (Darling, 2009). As the rise of the tent ward suggests, homeless encampments present a similar paradigm at the scale of the city. Although homeless people are not legally understood as internally displaced, they embody the underlying condition of placelessness that camps have historically sought to regulate. Homeless people in the US-as indicated by the terms "vagrant" and "vagabond"- -have long been characterized as strangers from elsewhere (Rahimian, et al. 1992). Today, social service agencies often perpetuate the "magnet myth" that homeless people are outsiders who flock to locations where services are well-provided (Foy, 2016). These mythologies of homeless outsiderness are grounded in notions of citizenship as property. Roy (2003, p. 476) writes that in the US, "as the paradigm of citizenship has come to be tied to property ownership, so the homeless have been seen as trespassers in the space of the nation-state." Arnold (2004) similarly argues that US citizenship is grounded in property ownership. She describes homeless people's condition of being excluded within the space of the nation as akin to Agamben's description of homo sacer-bare or naked life condemned to exist in liminal camps spaces. This exclusion can be seen as spatially and materially manifested over the past decade through the creation of tent wards.

Yet while camps resemble carceral spaces, they are distinct in that they are temporary sites, spatially designed to exist for a limited duration. Martin and Mitchelson (2009) further distinguish detention from incarceration in that inmates are not convicted of a crime but rather 
labeled with an indeterminate status and held in permanent limbo with no recourse to legal protections. In the US, homeless people in state custody are often viewed through both paradigms: as a criminal population, and as a group with no status or place of belonging. In this way, they sit at the nexus between detention and incarceration. As cities have increasingly coopted and controlled homeless communities on the street, they have developed new sites of homelessness management that blur the boundaries between camps and carceral spaces. In the section that follows, I examine how officials in Fresno, California imagined the space of the tent ward and how camp residents resisted its logics of incarceration.

\section{DEVELOPING TENT WARDS IN FRESNO, CALIFORNIA}

Fresno, California has long held the distinction of being one of the poorest cities in the US. In 2011, it also had the second-highest rate of homelessness in the nation (NAEH, 2012). Fresno has limited and disciplinary options for overnight shelter. To get a bed, homeless men must enter a drug treatment program either at the Rescue Mission or Poverello House. As a result, many homeless Fresnans rejected shelters "as too confining and conformist" (Hostetter, 2008). One camper opted to leave a shelter because "the limitations of that place were driving him nuts" (Saunders, 2009). Another man, Frank, told me in an interview, "I could never go stay in that Mission because they force certain things on you.... You have to do this. You have to do that." A 2013 survey asked more than 400 homeless Fresnans to identify an agency they trusted, and only $10 \%$ of respondents listed a shelter ("Fresno Madera," 2013, p. 29). Partly as a result of limited shelter options, beginning in 2002, multiple large-scale homeless encampments began to develop near the downtown area (Herring and Lutz, 2015). Encampments became increasingly spatially concentrated in the wake of a series of strict anti-homeless initiatives, including an anti- 
panhandling law and crackdowns on loitering and shopping cart possession (NLCHP, 2014). Over the years, the city seesawed between tolerating the encampments-sometimes for long stretches - and bulldozing them completely. In 2004, officials began seeking an alternative.

As part of a new initiative, the city collaborated with the Poverello House-Fresno's largest homeless service center-to create a sanctioned encampment on the same site where an illegal encampment was previously demolished. The "Village of Hope" was comprised of tents arranged in rows and surrounded by a high fence, in stark contrast to the illegal tent cities clustered just outside the fence. The city re-zoned the property as a campground, bypassing building codes that required running water, weather-safe materials, and fixed sanitation. Over time, the tents were replaced by 66 tool sheds arranged in the style of an army barracks, each containing two cots and sleeping bags. At the Village, residents could not keep pets, were subject to random property searches, and had to abide by restrictions on romantic partnering. They were forced to leave early in the morning and were locked out of their sheds if they returned too late in the evening (Kincaid, et al. v. Fresno, 2006). Nonetheless, the project provided people with security and allowed homeless residents to maintain a semblance of autonomy (Herring and Lutz, 2015). The Village was touted as a success and as a "mutually supportive" and "self governing” community (Levine \& Glassel, 2004).

By 2007, the city council voted to create a second encampment on the shelter's property. Under the agreement, the Community of Hope was born, with the Poverello House to receive $\$ 10,000$ per month for operating costs $(\mathrm{NCH}, 2010)$. The Community afforded residents fewer opportunities for self-governance than the Village of Hope. The Poverello House maintained "absolute control" over the Community and mandated a ban on drugs, alcohol, flames, candles, incense, and "untidy space" (City of Fresno, 2007). Residents were required to perform two shifts 
of security each week and forced to leave the camp each morning (NCH, 2010). Both encampments, which sat adjacent to each other on the same property, were referred to collectively as "The Villages."

In 2013, I interviewed officials who were involved in the creation of these facilities to get a sense of how and why they were developed. Jim Connell, the executive director of the Poverello House, told me about his role in the creation of The Villages:

In an effort to get the illegal encampment cleaned up, I said we could fence off an area and put tents in there for those that were willing to agree to some sort of rules. And so what we did was we gathered those people together and said, "Look, we'll do this, but you people have to be involved."

He told me The Villages closed during the day "to encourage people to get out and go find a job, do something." His language illuminates his perceived responsibility to "gather people together" and implies that homeless people will not "do something" with their lives unless they are coerced. Within the shelter itself, a large windowless building adjacent to The Villages where people received daily meal services, beds were provided to those who had entered a drug treatment program. Most people sleeping overnight at the shelter were completing jail diversion requirements. Connell described the program:

It's a pretty structured program. They have homework they have to do.... They're assigned a job. ... They have a jail sentence hanging over their head, which gives them a little encouragement to stay in the program. ... You've got to start training them, resocializing them. You get up in the morning. You brush your teeth. You make your bed. They've lost all those disciplines. If your job starts at 8 o'clock, you're there at 8 o'clock. It's sort of a retraining process and them taking responsibility for their lives.

Thus, the shelter collaborated closely with law enforcement agencies and promoted paternalistic policies aimed at normalizing residents. The Villages, as extensions of the shelter, followed a similar rationale. 
Robert Levine, a psychology professor and board member of the Poverello House, helped oversee the management of The Villages. He co-authored an article with Ron Glassel, one of the founding residents of the Village of Hope. Levine and Glassel (2004) conclude with a series of questions:

Should residents be required to demonstrate progress toward finding jobs and/or stable housing? Should there be absolute limits—say 90 days or one year-on stays? And, if so, what will happen to the lifers? In a new experiment, residents will be required to come up with an individual development plan for the next six months. The effects of this requirement will be closely monitored. With winter coming, Poverello House is currently replacing the tents with more durable and weather-resistant structures. Even this, however, raises questions: Will more comfortable quarters discourage residents from moving forward? (Levine \& Glassel, 2004)

The hesitance to provide residents a modicum of comfort suggests that homeless people might rise above their conditions if they are uncomfortable enough to want something better. These sentiments — although grounded in care and compassion — are also rooted in the idea that homelessness is the result of individual failures, rather than structural poverty and inequality. In this way, benefaction becomes tinged with authority and coercion.

Sherry Oliver, who ran a local women's shelter, also supported the creation of a sanctioned camp. She envisioned strict top-down organization, and praised Professor Levine's efforts in directing "the social organization" of The Villages. She further rejected the provision of support to existing encampments and instead advocated for the need to bring in an expert—in this case, a university professor - to develop entirely new encampments. As with Connell and Levine, she saw self-made homeless communities as incapable of creating positive social organization. Oliver also identified location as a key aspect of any proposed encampment and saw spatial segregation as a strategy to prevent certain neighborhoods from bearing the burden of homelessness. She said: 
It is an issue of location, because obviously you don't want this encampment to be located here. That's hurting your services and your ability to provide them. And then I think that becomes a problem for whatever neighborhood it's located in. ... Up here, it's right in people's back yards.

Oliver envisioned a camp remote from residential areas so that no-one's "backyard" would be affected by its presence. Thus, the official camps should not only be regulated but also invisible and spatially predetermined.

In 2007, several city officials advocated for the creation of a 30,000 square-foot encampment in an industrial neighborhood south of downtown. The lot had no access to shade and was fenced in on all sides. The mayor envisioned an encampment that would be monitored by the county. Simultaneously, the city proposed an ordinance to ban camping. At the city council meeting debating both proposals, councilmember Jerry Duncan characterized the camping ban as "a consequence to people not wanting to become productive citizens" (City Council, 2007). On a local conservative talk radio show, he announced the proposal's goal to remove all encampments from the downtown area and contain Fresno's homeless community on a plot of land where they would not be as visible (Rhodes, 2007b). Not only was the plan aimed at making homelessness invisible, but it also was a "consequence" for people who failed to "become productive." Thus, Councilman Duncan did not only frame the plan as a way to shelter people, but to punish them for not working and render them invisible to the wider public.

Larry Arce, former probation officer and CEO of the Rescue Mission, was one of the driving forces behind the proposal for the remote sanctioned camp. When I asked about his vision for the site, he explained:

We'll designate that area. If you want to camp out, you don't want to go into a program, you have to go here. But also what our intent was, the only place you can go to, we'll concentrate services there, like probation, parole, court services, social security, all the different things that the homeless need. ... And then the intent is to funnel them into a 
program. You can only be there so long, but in the meantime while you're here, we're making an assessment of putting you into a program.

Thus, Arce's vision involved criminalization of homelessness, such that homeless people would have only one place to go in the city, where management and criminal justice systems could "funnel" them into various programs. He viewed the tent ward as an instrument by which the city could filter the complex and ungoverned crowd that resides in homeless encampments into different spaces of surveillance and containment. According to his vision, criminals would go to jail, the mentally ill to institutions, and addicts into programs.

Arce's model for the tent ward resembles the way he ran the Mission. The shelter previously had an open-door policy until Arce began requiring residents to conform to a strict Bible-based drug treatment program. He told me that once he initiated the new program and "got rid of the deadbeats," shelter residency was drastically reduced. He saw homelessness and drug addiction as a form of sin: "You rebelled against society. You rebelled against your family. You rebelled against God. You want to do your own thing. You don't want nobody to tell you what to do. And that's sin.” Thus, shelter at Fresno's Rescue Mission was attached to submission to religious norms. The Mission also oversaw an outdoor jail facility and partnered with the police department to commit intoxicated men for a 24-hour period, including during sweltering hot summers and freezing winters. Local activists have called this site a "drunk tank" and a “concentration camp" (Rhodes, 2004). One activist who had previously worked in a drug treatment facility told me, "There have been times when the Rescue Mission has people detox in their parking lot with no supervision, and people [can] die because of that." This outdoor "detox" space was akin to Arce's vision for a sanctioned encampment that would function as an ad hoc space to contain "rebellious" communities.

Mike Rhodes is a local activist involved in homelessness advocacy. He told me in an 
interview that Bruce Rudd, the Assistant City Manager at the time, asked if he could "get everybody to go [to the proposed encampment]." Rhodes recalled that Rudd's request framed homeless people as childlike and compliant: "I said, 'What do I look like to you? The pied piper of the homeless?" He described the first time he saw the site for the proposed encampment:

It's pretty desolate area. And so the place had a fence around it all. There was no shade, and there was like just tons of goat head thorns, which are these really harsh thorns that, you step on them, you know it. ...Why would anybody go there, and live in the hot sun? There's no shade. There's no services. There's nothing there.

In highlighting the lack of services, Rhodes was not referring to the "court services" that Arce envisioned, but rather to the lack of food, water, sanitation, or health services available nearby. As with many sanctioned camps in cities across the nation, officials predetermined the location without consulting homeless communities, and selected a site that was distant from visible downtown spaces as well as the services that are essential to homeless people's survival. This predetermined and remote siting is yet another manifestation of the spatial control of homeless people's lives. Yet the plan was vehemently rejected by nearby industrial businesses, as well as local homeless people, and it failed before it was ever built.

In 2013, the city again floated plans to build a remote tent city south of the downtown area, immediately adjacent to the railroad tracks and a recycling facility. The neighborhood was a thirty-minute walk from services and had few sidewalks or pedestrian pathways. When I visited the site, the area was completely fenced in, had no shade, and was riddled with thorns. It seemed to repeat the 2007 plan. Meanwhile, officials also sought to create a homeless campus, following the model of St. Petersberg's “jail-ter" and San Antonio's Haven for Hope, which include a concrete area for hundreds of homeless people to sleep on mats in the open air (Hayward, 2011). Fresno officials traveled to San Antonio to learn from the model, and several officials told me it was the direction Fresno planned for the future. In seeking a consultant on the 
project, the Fresno Business Council and several homelessness agencies hired Robert Marbut, the CEO of Haven for Hope, a man who regularly advises cities on homelessness management and has been referred to as a "homelessness guru" (Dunwoody, 2014).

In his advisory report, Marbut recommended that Fresno unite homeless services with the criminal justice system. In particular, he proposed a project that would be located near the jail to maximize jail diversion efforts and bring homeless individuals into "365 days-a-year programming" (Marbut, 2014, p. 9). The project would include intensive screening and "lowdemand shelter" (Marbut, 2014, p. 22). Marbut wrote:

A physical fencing barrier needs to line the facility. If possible, foliage or other screening should be integrated within the fencing system to create a visually aesthetic barrier. Additionally, the structures within the come-as-you-are center need to be laid out in such a way as to create positive ergonomic flow and defensible space. (Marbut, 2014, p. 23)

Marbut also explicitly recommended a model of reward and punishment: "Too often there are no consequences for negative behavior of individuals. Unfortunately, this sends a message that bad behavior is acceptable. Within the transformational process, it is critical to have swift and proportionate consequences" (Marbut, 2014, p. 32). Again, the proposal for a sanctioned encampment was rooted in the quest for homeless surveillance and confinement.

In cities across the US, sanctioned encampments often do not appeal to homeless people as a viable option for shelter. Even when city-developed encampments provide superior access to amenities and food, homeless people often prefer self-organized encampments for the “community, autonomy, and privacy" they afford residents (Wright, 1997, p. 249). As Ehrenreich (2009) wrote of Ontario's encampment, “The rules were infantilizing. ... More than a third of those permitted to stay in the [encampment] have left for good." In Fresno, the situation was similar. Despite the lack of alternative shelter, in the summer of 2006, the occupancy rate at The Villages was only 50-60\% (Kincaid, et al. v. Fresno, 2006). When I asked Jim Connell about 
the low occupancy in 2013, he speculated that it was because residents were not allowed to use drugs. He did not suggest that the desire for autonomy might also be a compelling reason.

LoriAnne Tennison, a onetime resident of the Community of Hope, spoke out against The Villages. She recalled that every evening, shelter staff would open the door to her shed to make sure she was there. When she asked staff to knock first, they refused. Staff also took away extra sleeping bags she had procured to protect herself against the cold, and threatened to kick out any resident seen interacting with "street people," including their own family members (Tennison, 2011). In an article published in the local progressive newspaper called "Surviving the Village," Tennison (2011) wrote that stringent rules are "meant to take away whatever personal power that a person may possess, to destroy the ability of self-determination." Ultimately, she was kicked out for failing to be present at a 4:30 am homelessness survey. She wrote: "I am now one of those 'bad people' who live on the street and sleep in a tent."

Louis, a middle-aged man who had recently received supportive housing, had previously elected to live in a street encampment because the rules at The Villages were too restrictive. He told me in an interview, "I couldn't stay there. I had sources of going there, but I had to have my own tent. I like to come and go as I please. ... They kick you out in the morning and you can't come back till a certain time in the day." Management also had the power to kick people out permanently. Brandy, a 21-year-old pregnant woman told me that she was recently forced to leave:

They said because me being pregnant, I'm considered a health risk. So at six months I had to leave. ... It's not necessarily [that I wanted to have] a baby in the shed. It's just keeping stable until you get somewhere to go, which I didn't even have the chance to.

Frank, who lived at the Village of Hope when I interviewed him, told me he had to "break down" to follow the pervasive rules: "There's rules everywhere. You just got to learn and break down 
and follow the rules. And if you don't do that, you're bye-bye. You're back out there." While sanctioned encampments provided security, aid, and access to sanitation, they often stripped people of whatever sense of autonomy they possessed.

Homeless Fresnans also publicly voiced their opposition to the creation of new tent wards. In 2007, tent city residents spoke out at a City Council meeting against the proposed 30,000 square foot encampment. Speaking before the council, Alphonso Williams, a prominent homeless activist, said, "you are trying to put people into a concentration camp. ... I'd rather be in jail than a concentration camp" (Rhodes, 2007b). Homeless activists also pushed for the legalization of autonomous street encampments. Cynthia Greene spoke against a proposed anticamping ordinance, saying, "If this ordinance is passed it will be challenged. It was challenged in Los Angeles and they had to back down because it is not good for the people" (Rhodes, 2007b). One camper said what people need most is a "someplace that they can go 24/7 without worrying about having to leave" (KNXT1, 2012). Collectively, protesters argued that by funneling all campers into a single heavily surveilled site, the city was stripping away the heterogeneity and autonomy of existing communities.

Yet officials I spoke with were consistently opposed to the notion of legalizing existing campsites. A local councilman saw it as an impossible project:

Because of liability, the city would probably have to have a fence around it. The city would probably regulate who came in and went out. The city would probably have to have police officers there, or security people there. And there's one thing I know about homeless, is they don't go where police officers and security people are. So I think it's a non-starter.

He saw securitization and fencing as necessary and inevitable, yet he knew it was not a solution local campers would accept. Jim Connell also opposed legalized camping. He said, "Some people came up with the idea of sort of a legalized campground. ... It really doesn't work 
because it degenerates into what we've got going on now. The whole criminal element taking control of it." When I asked him what distinguished an illegal encampment from The Villages, he said, "We control sort of the element that goes in there. That's the piece we control with The Villages. We keep out the criminal element." Thus, he viewed management and screening as necessary components of any successful homeless community. Levine and Glassel (2004) articulated a similar rationale in describing the encampment that was demolished to make room for the Village of Hope:

The shantytown began innocently enough but, by December, was plagued by violence, drugs, prostitution, open fires and filth. The police and Poverello House decided to tear down the shantytown and to simultaneously create an alternative facility for those willing to obey the law.

The description of street encampments as filthy and criminal implies that homeless self-

governance is a dangerous enterprise and that a competent caretaker must intervene to protect the community from itself. This language also illuminates the way in which discourses of homeless criminality come to shape the spaces where homeless people can exist in the city.

Yet Fresno homelessness management was not a monolith, but a complex landscape marked both by care and criminalization. The city was home to a well-organized church-based advocacy group that brought weekly donations to homeless encampments. Local activists also made a private residence available for a small group of campers to reside in semi-permanent outdoor shanties, with access to a vegetable garden and collective kitchen facilities. Further, many people who worked in the shelter system expressed empathy for those experiencing the hardships of homelessness. Two officials I interviewed were frustrated with the tent ward model. A manager at the Fresno Housing Authority told me she did not believe in "warehousing the homeless." Another official with the county said of the proposal: 
What I'm afraid of is we become complacent if we don't have to see people anymore. ... We're not going to incorporate them into society. We're gonna house them over here in this one district and it's policed and there's barbed wire on top and there's people with guns that don't let you out of there. ... It just makes it easier to push the problem aside.

Yet both officials rejected homeless campers' requests for support and legalization of currently existing encampments. Thus, they saw no option but to yield to the dominant ideology that supported the tent ward model.

Beyond the tent ward proposals, homelessness management more broadly was often framed through the lens of law enforcement. In July 2013, a man was shot and killed near one of the encampments. Although neither of the suspects were homeless, the city argued that homeless encampments were the source of the violence. The Fresno Bee issued an article stating, "The murder in the Santa Clara camp last year was a tipping point. City officials said the camps had to be razed because they were public-safety hazards to homeless and non-homeless alike. No one can ever again suggest otherwise" (Hostetter, 2014). After the shooting, Fresno police began an aggressive arrest campaign in the encampments. The city issued a press release stating that the camps were riddled with criminal activity, as there had been 82 arrests over the past several weeks. The police chief said of the encampments:

There is a misperception that people at the encampments are simply folks who are down on their luck... The reality is that gang members and other criminals have moved there and are taking advantage of the people who are truly homeless. (Hastings, 2013)

Yet when I interviewed the police chief, he told me that most of the arrests were for outstanding warrants and parole violations. Among the people arrested for violent crimes, only one of them lived at the encampments. Although most homeless arrests were for minor offenses, officials responded with an unprecedented wave of demolitions. Not only did the city announce that it would destroy every encampment in the city, but it also set up a police "task force" to prevent anyone from camping in the future. 
Fresno is a historically conservative city, and the police department has long been a powerful local influence. In 2012 , nearly $80 \%$ of the city's budget went to public safety, much of which went to the police department (Hostetter, 2012). Advocates have charged that community block grant money for the homeless was rerouted to the police department for evictions (Rhodes, 2007a). In 2013, the police department quickly became a primary driver behind Fresno's eviction policies. Simultaneously, it was integral to the Continuum of Care, the local network of homeless management organizations, along with four other law enforcement and corrections agencies (Continuum of Care, 2012). Jails themselves also took on a key role in the management of homelessness. In 2013, the county jail was so overcrowded it had to plan for a major expansion. Even Marbut (2014, p. 14), in his report recommending highly disciplinary camp spaces, acknowledges that Fresno's emergency room and the jail became "the de facto alternatives to treatment," which led to "the overloading of the criminal justice and emergency health service systems."

Beyond the police department, shelter operators I spoke with also characterized encampments as sites of heightened criminality. Sherry Oliver was concerned when I told her I was doing interviews in the camps. She said, "I wouldn't want to walk down the middle of that street. I drive down there because I want to see what's going on. Now I doubt that they'd harm us because they know who we are. But I certainly wouldn't carry a purse." Jim Connell advocated for police intervention, saying:

That encampment out there, if I had to guess, is $98 \%$ there because of drugs. ... Even if you could house everybody who's amenable to housing, you're still going to have a certain population left on the street that's the criminal and addictive element and the criminal justice system has to deal with those people.

Robert Marbut similarly claimed that violent crimes were common in the encampments: 
The homeless encampments in Fresno have taken on a structure and scope not seen anywhere in the USA. ... Fresno's encampments resemble the impoverished shantytowns of Africa and Latin America.... There are several indictors [sic] that the encampments are one of the most (if not the most) violent homeless populations in the United States. Stabbings, shootings and arson fires are routine occurrences within these encampments. (Marbut, 2014, p. 6)

In evoking the horror of shantytowns in "Africa and Latin America," Marbut promotes racist tropes about dangerous black and brown communities outside the US. Snow, Baker and Anderson (1989) argue that the perception of the homeless as dangerous is not uncommon, despite the fact that homeless people do not commit violent crimes more often than the population at large. Such discourses of homeless criminality mirror the racism that undergirds larger structures of US policing and mass incarceration. They further ignore that for many, the camps were places of security and had their own organization with intrinsic leadership and provision of services.

Homeless people I spoke with overwhelmingly resisted portrayals of the camps as criminal hotbeds. Mary, who lived in an encampment near an irrigation canal, told me in an interview, “They think we're all drug addicts. ... We're all individual people, you know. There's assholes in every group, but we're not here by choice." In a news report on the encampment evictions, Virginia Lopez said, "They say that this is all happening because of all the crimes and all the drugs and all of that. Well, we're not even into that" (thefresnobee, 2013). Indeed, camp residents overwhelmingly represented encampments as safe and collectively organized neighborhood spaces (Speer 2016; 2017). As Virginia Garcia said of her tent city neighbors, "They want to be around other people. They feel safer" (Hostetter, 2008). In a radio interview, Nancy Holmes echoed a similar sentiment: "Until I was found and went to [this] camp, that's the only time during my homeless time that I felt at home and I felt safe" (Homelessness Marathon, 
2014). These statements stand in stark contrast to official representations of street encampments as dangerous spaces in desperate need of surveillance and policing.

Beyond Fresno, street encampments provide a unique space where homeless people can resist the pathologizing and punitive aspects of homelessness management (Mitchell, 2012; Sparks, 2017). Yet as cities turn to sanctioned camps instead of shelters, they establish a disturbing precedent in the geographies of homelessness management. Beyond linking carceral and welfarist modes of governance, tent wards also evoke the long historical legacy of camps as sites of state brutality. As Sparks (2017, p. 353-354) writes:

It is a perverse present in which ... camps are the only places where the houseless might have some hope of exercising their most basic human rights. ... If the twentieth century taught us anything, it is that when camps become spaces for confinement and quarantine for society's unwanted, things seldom turn out well. This danger looms especially large when those who must live in the camps are considered deviant, less than human, and unable to speak or act in their own best interest.

This danger becomes even starker when camp spaces are co-opted by state and private authorities. Fresno's push for tent wards suggests that officials do not criminalize camping because they are opposed to people living in tents and shanties, but rather because illegal encampments provide collective, ungovernable space. While tent wards provide people a safe place to sleep at night — however temporary and inadequate — they simultaneously deny them the ability to produce their own urban spaces or govern their own mobility.

\section{$\underline{\text { CONCLUSION }}$}

The carceral approach to homelessness itself is never all-encompassing, as each city has its own complex history and politics of homelessness management. Indeed, many cities have well-funded shelter and housing systems and are developing innovative ways of responding to homeless encampments. Fresno, with its intractable problems of extreme poverty, underfunded 
services, and failure to revitalize, experienced intense political pressure to remove and contain homeless autonomy and mobility. Yet even in Fresno, small acts of care and compassion provided respite for homeless campers amidst the brutality of evictions and criminalization. Indeed, local officials developed tent wards not only to manage homelessness through the logic of crime, but to create new spaces for service provision. It was precisely this combination of welfare and discipline that made submission—or as Frank said, "breaking down and following the rules" - a prerequisite to receiving much-needed aid. This process shows how carceral modes of homelessness management became pervasive in Fresno, and how the social crisis of poverty was reduced to problem of spatially managing homeless people themselves.

Beyond Fresno, tent wards shed light on a larger nexus between welfare and incarceration. In cities that prioritize the goal of spatial management and discipline, quasicarceral spaces have become a tool through which to provide homeless services. In turn, such services have been reduced to the bare minimum: tents, tool sheds, and mattresses in the open air. As temporary and easily dismantled sites, tent wards are a relatively affordable and flexible means for local governments to provide emergency services in the ongoing crisis of homelessness, while also surveilling homeless people and relocating them away from prime urban areas. In this way, tent wards demonstrate the historical failure of US cities to create lasting and equitable platforms that address the problems of urban poverty, and to instead identify poor people as a problematic population that must be cared for, as well as spatially controlled.

The phenomenon of tent wards also reveals connections between carceral and camp spaces more broadly. While camps are temporary sites to manage and provide for those who are otherwise placeless, incarceration solidifies the makeshift nature of the camp. As with 
Agamben's notion of the camp, incarceration creates a category of placeless "others" by moving people to distant and confined spaces, stripping them of their full rights, and denying them control over the geographies of their lives. In this light, both camps and carceral spaces are stopgap measures that seek to produce and contain outsiders to avoid confronting the pressing and intractable problems of social inequality and exclusion. Thus, and perhaps most importantly, carceral space can be understood as a temporary fix — rather than a static or permanent projectthat remains incomplete, ongoing, and open to resistance.

\section{$\underline{\text { REFERENCES }}$}

Agamben, G. (1998). Homo sacer: Sovereign power and bare life. Stanford, CA: Stanford University Press.

Amster, R. (2008). Lost in space: The criminalization, globalization, and urban ecology

of homelessness. New York, NY: LFB Scholarly Publishing.

Arnold, K. R. (2004). Homelessness, citizenship, and identity. Albany, NY: State

University of New York Press.

Beckett, K., \& Herbert, S. (2010). Penal boundaries: Banishment and the expansion of

punishment. Law \& Social Inquiry, (35)1, 1-38. 
Brown, E. (2014). Expanding carceral geographies: Challenging mass incarceration and

creating a "community orientation" towards juvenile delinquency. Geographica Helvetica, 69(5),

377-388.

Carlson, C. (2004, March 8). Key West says homeless must leave wetlands. Ventura

County Star, p. 1.

Chapman, C., Carey, A., \& Ben-Moshe, L. (2014). Reconsidering confinement:

Interlocking locations and logics of incarceration. In Ben-Moshe, L., Chapman, C., \& Carey, A.

(Eds.) Disability Incarcerated: Imprisonment and Disability in the United States and Canada

(pp. 3-24). New York, NY: Palgrave Macmillan.

City Council Meeting Minutes. (2007, June 19). City of Fresno.

City of Fresno. (2007, October 2). Report to the City Council re: Appropriation for

Poverello House/Village of Hope.

Continuum of Care Application. (2012, January 3). Fresno/Madera County Continuum of

Care.

Crouse, J. (1986). The homeless transient in the Great Depression: New York State,

1929-1941. Albany, NY: State University of New York Press. 
Crystal, S., \& Goldstein, M. (1982). Chronic and situational dependency: Long term

residents in a shelter for men. New York, NY: Human Resources Administration of the City of

New York.

Darling, J. (2009). Becoming bare life: Asylum, hospitality, and the politics of

encampment. Environment and Planning D: Society and Space, 27(4), 649-665.

Davis, M. (1990). City of quartz: Excavating the future in Los Angeles. London, UK:

Verso Books.

DeVerteuil, G. (2006). The local state and homeless shelters: Beyond revanchism? Cities, 23(2), 109-120.

DeVerteuil, G., May, J., \& Von Mahs, J. (2009). Complexity not collapse: Recasting the geographies of homelessness in a 'punitive' age. Progress in Human Geography, 33(5), 646-666.

DeWard, S. L., \& Moe, A. M. (2010). Like a prison: Homeless women's narratives of surviving shelter. Journal of Sociology and Social Welfare, 37, 115-135.

Dordick, G. A. (1996). More than refuge: The social world of a homeless shelter. Journal of Contemporary Ethnography, 24(4), 373-404. 
Dunwoody, D. (2014, March 14). Homeless guru speaks in Pensacola. WUWF Public

Media.

Ehrenreich, B. (2009, June 22). Tales of the tent city. The Nation Magazine.

Felder, M., Minca, C., \& Ong, C. E. (2014). Governing refugee space: The quasi-carceral regime of Amsterdam's Lloyd Hotel, a German-Jewish refugee camp in the prelude to World

War II. Geographica Helvetica, 69(5), 365-375.

thefresnobee. (2013, September 3). The City of Fresno begins sweep of second homeless camp [video file]. Retrieved from https://www.youtube.com/watch?v=aG8RJDDWnf8

The Fresno Madera Continuum of Care Point in Time Count. (2013).

Foucault, M. (1995). Discipline \& punish: The birth of the prison. New York, NY:

Vintage.

Geller, A., \& Curtis, M. A. (2011). A sort of homecoming: Incarceration and the housing security of urban men. Social Science Research, 40(4), 1196-1213.

Gill, N. (2013). Mobility versus liberty? The punitive uses of movement within and outside carceral environments. In Moran, D., Gill, N. \& Conlon, D. (Eds.), Carceral spaces: Mobility and agency in imprisonment and migrant detention (pp. 19-36). Farnham: Ashgate. 
Gilmore, R. W. (2007). Golden gulag: Prisons, surplus, crisis, and opposition in globalizing California. Berkeley, CA: University of California Press.

Gowan, T. (2002). The nexus: Homelessness and incarceration in two American cities. Ethnography, 3(4), 500-534.

Greenberg, G. A., \& Rosenheck, R. A. (2008). Homelessness in the state and federal prison population. Criminal Behaviour and Mental Health, 18(2), 88-103.

Hastings, B. (2013, October 30). Fresno attempts to 'clear' out the homeless. The Rampage Online. Retrieved from http://www.therampageonline.com/news/2013/10/30/fresnoattempts-to-clear-out-the-homeless/

Hayward, S. (2011, February 3). Haven for hope, where homeless find haven from cold.

Nowcast San Antonio.

Heben, A. (2014). Tent city urbanism: From self-organized camps to tiny house villages. Eugene, OR: Village Collaborative.

Herring, C. (2014). The new logics of homeless seclusion: Homeless encampments in America's west coast cities. City \& Community, 13(4), 285-309. 
Herring, C., \& Lutz, M. (2015). The roots and implications of the USA's homeless tent

cities. City, 19(5), 689-701.

Hostetter, G. (2008, November 9). Homeless sprawl - Fear of some areas downtown prompts Fresno's homeless population to seek safer public places. The Fresno Bee, p. A1.

Hostetter, G. (2012, December 2). Tough decisions - Her first terms was a doozy. Now, Fresno mayor Ashley Swearengin gears up for her second round. The Fresno Bee, p. A1.

Hostetter, G. (2014, February 25). Homeless workshop highlighted big change in Fresno.

The Fresno Bee City Beat.

Hunter, J., Linden-Retek, P., Shebaya, S., \& Halpert, S. (2014). Welcome home: The rise of tent cities in the United States. Washington, DC: National Law Center on Homelessness \&

Poverty.

Irwin, J. (1985). The jail: Managing the underclass in American society. Berkeley, CA:

University of California Press.

Kelly, D. (2008, March 17). Officials thin ranks in homeless tent city. Los Angeles Times.

Kincaid et al. v. City of Fresno. (2006). Statement of decision and findings re: Plaintiffs'

application for a preliminary injunction. 
KNXT1. (2012, March 7). Fresno's homeless: What's next [video file]. Retrieved from

https://www.youtube.com/watch?v=i4y9p4agiMs

Levine, R., \& Glassel, R. (2004, December). A village of hope. Newsletter of the NGO

Committee on Human Settlements, 2, 5.

Loftus-Farren, Z. (2011). Tent cities: An interim solution to homelessness and affordable

housing shortages in the United States. California Law Review, 99(4), 1037-1082.

Longley, K. (2006). Governing homelessness: The politics of tent cities in the US.

Boston, MA: John W. McCormack Graduate School of Policy Studies Student Research

Conference.

Lynnwood Municipal Code, Title $21 \S 74$ (2014).

Marbut, R. (2014). Fresno Restoration Project Strategic Action Plan. Strategic

Development Solutions.

Martin, L. L., \& Mitchelson, M. L. (2009). Geographies of detention and imprisonment:

Interrogating spatial practices of confinement, discipline, law, and state power. Geography

Compass, 3(1), 459-477. 
Metraux, S., Caterina, R., \& Cho, R. (2008). Incarceration and homelessness.

Washington, DC: National Symposium on Homelessness Research.

Minca, C. (2015). Geographies of the camp. Political Geography, 49(9), 74-83.

Mitchell, D. (1997). The annihilation of space by law: The roots and implications of anti-

homeless laws in the United States. Antipode, 29(3), 303-325.

Mitchell, D. (2012). Tent city: Spaces of homeless survival and organizing in the

American city. In Phillips, A. \& Erdemci, F. (Eds.) Social Housing -Housing the Social: Art,

Property, and Spatial Justice (pp. 277-306). Amsterdam, Netherlands: SKOR and Sternberg

Press.

Moran, D. (2015). Carceral geography: Spaces and practices of incarceration. Farnham,

UK: Ashgate.

Moran, D., Turner, J., \& Schliehe, A. K. (2017). Conceptualizing the carceral in carceral geography. Progress in Human Geography, DOI: 0309132517710352.

NAEH (The National Alliance to End Homelessness). (2012). State of homelessness in America. Washington, DC. 
NCH (The NCH for the Homeless). (2010). Tent cities in America: A Pacific Coast

report. Washington, DC.

NLCHP (The National Law Center on Homelessness and Poverty). 2014. No safe place:

The criminalization of homelessness in US cities. Washington, DC.

Piven, F. F., \& Cloward, R. (1971). Regulating the poor: The functions of public welfare.

New York, NY: Vintage.

Peck, J., \& Theodore, N. (2008). Carceral Chicago: Making the ex-offender

employability crisis. International Journal of Urban and Regional Research, 32(2), 251-281.

Rahimian, A., Wolch, J., \& Koegel, P. (1992). A model of homeless migration: Homeless

men in Skid Row, Los Angeles. Environment and Planning A, 24(9), 1317-1336.

Rhodes, M. (2004, May 6). Concentration camp for the homeless. The Community

Alliance Newspaper.

Rhodes, M. (2007a, February 23). Poor people gonna rise up! The Community Alliance

Newspaper.

Rhodes, M. (2007b, June 20). Will Fresno's homeless people be put into a concentration

camp? The Community Alliance Newspaper. 
Sabol, W., West, H., \& Cooper, M. (2009). Prisoners in 2008. Washington, DC: Bureau

of Justice Statistics.

Saunders, G. (2009, September). Tent city, USA. GQ Magazine [Audio Slideshow].

Simon, J. (2007). Governing through crime: How the war on crime transformed

American democracy and created a culture of fear. Oxford, UK: Oxford University Press.

Snow, D. A., Baker, S. G., \& Anderson, L. (1989). Criminality and homeless men: An

empirical assessment. Social Problems, 36(5), 532-549.

Sparks, T. (2017). Neutralizing homelessness, 2015: Tent cities and ten year plans.

Urban Geography, 38(3), 348-356.

Speer, J. (2016). The right to infrastructure: A struggle for sanitation in Fresno,

California homeless encampments. Urban Geography, 37(7), 1049-1069.

Speer, J. (2017). "It's not like your home": Homeless encampments, housing projects, and the struggle over domestic space. Antipode, 49(2), 517-535.

Spokane Municipal Code, Title $10 \S 08 C$ (2014).

Stark, L. (1994). The shelter as 'total institution.' The American Behavioral Scientist,

$37(4), 553-562$. 
Stuart, F. (2014). From 'rabble management' to 'recovery management': Policing

homelessness in marginal urban space. Urban Studies, 51(9), 1909-1925.

Tennison, L. (2011, March 1). Surviving the Village: An organizer's tale. The

Community Alliance Newspaper.

Turner, C. (2017). It takes a village: Designating "tiny house" villages as transitional housing campgrounds. University of Michigan Journal of Law Reform, 50(4), 931-955.

Foy, M. S. (2016). Transience and homelessness in the River District: Exploring the magnet myth. (Doctoral dissertation, California State University, Sacramento).

HUD (US Department of Housing and Urban Development). (2009). The 2008 annual

homeless assessment report to congress.

Wacquant, L. (2009). Punishing the poor: The neoliberal government of social insecurity. London, UK: Duke University Press. 